\title{
An externally dependent economy and real estate bubbles
}

\author{
Lijian Sun and Shengxing Zhang
}

The two prominent phenomena in the world economy in recent years have been excessive monetary liquidity and asset price bubbles (Bank for International Settlements 2004; United Nations 2006; OECD 2006). In the past, Western industrialised countries experienced different kinds of bubbles, for example: information technology (IT) stock bubbles from 1996 to 1999; bond price bubbles from 2000 to 2002; and real estate bubbles from 2002 until now. Although each bubble had specific characteristics (Hunter et al. 2005), ${ }^{1}$ the latest research shows that excessive monetary liquidity is an indispensable factor in explaining recent price bubbles in capital markets-for example, stock, bond and real estate markets (Issing 2002; Gouteron and Szpiro 2005).

The co-movement of excessive monetary liquidity and asset price bubbles began to attract economists' attention as early as 1929 with the start of the Great Depression. At that time, economists agreed that a lending boom would stimulate bubbles in capital markets (White 1990). Specifically, for the case of the Japanese bubble economy in the late 1980s, many Japanese scholars also pointed out that the Japanese government's expanded monetary policy during yen appreciation resulted in stock and real estate bubbles. Some have described the Japanese economy as suffering from depression because of the bursting of the bubble (Okina and Shiratsuka 2005). On the other hand, many other researchers explain that tight monetary policy can induce the collapse of financial markets (Friedman and Schwartz 1982; Bernanke 2001; Posen 2006). Much recent empirical research, however, reveals that there is no direct causal link between a central bank's monetary policy and asset price bubbles 
(Bordo and Jeanne 2002; Mishkin and White 2002; Detken and Smets 2004). In this sense, monetary policies are neither the cause of nor the cure for asset price bubbles.

Nevertheless, monetary liquidity has now become obviously excessive all over the world, so the key point is to uncover the main cause of this phenomenon and its relationship with asset bubbles. In recent years, many scholars have explained the mechanism of excessive liquidity. Ortalo-Magne and Rady (2006) argued that the impact of business cycles on personal income induced changes in monetary liquidity, which in turn influenced housing demand, causing surges in real estate prices. Additionally, a lack of investment channels would force investment to concentrate in well-behaved markets so that speculative bubbles in these markets became increasingly pervasive (Ventura 2004; Caballero and Krishnamurthy 2005). Other scholars found that in bank-based countries, real estate bubbles and collapses were common, which was an outcome of the myopic behaviour of banks: when the economy was booming, banks increased lending for real estate purchases when prices were rising, and cut lending when real estate prices were falling. Thus, the myopic behaviour of banks intensifies price fluctuation (Herring and Wachter 2005).

Excessive monetary liquidity in China is fierce and the growth rates of M1 and $\mathrm{M} 2$ are much greater than that of gross domestic product (GDP) (People's Bank of China 2006). Yuan and Fan (2003) and the research group of the China Real Estate Chamber of Commerce (2006) ${ }^{2}$ report that excessive monetary liquidity indeed leads to real estate bubbles, although it does not bring about high inflation in commodity markets, as the central bank worried it would. Sun (2006) indicates that the mechanism of real estate bubbles in China is significantly different from that in Western industrialised countries. Therefore, the objective of this chapter is to explore the reasons for excessive monetary liquidity in China and its impact on real estate prices.

From examination of the fundamental macroeconomic indices, and the overlapping generation (OLG) model explaining the high saving ratio of the younger generation (Tirole 1985), and using empirical analysis of provincial panel data, we make three contributions. First, we examine the logic behind real estate bubbles in China. We focus on the way that excessive monetary liquidity - as the root of real estate bubbles_results from the increasingly externally dependent economic structure. Second, we test the view that excessive monetary liquidity does not stimulate private consumption because residents are less confident of maintaining their incomes. On the contrary, it increases the burden on the banking system by encouraging excessive private savings as a result of inefficient capital markets. Third, we look at how real 
estate bubbles are a result of private precautionary savings. While each agent, including banks and individuals, tries to invest in assets with safe and high returns, the aggregate result is over-investment in these assets. The risk of a 'credit crunch' thus increases and social welfare is impaired.

Admittedly, some scholars have also investigated the influence of surpluses in the balance of payments on asset prices in emerging markets. For instance, Park and Park (1995) take the example of financial liberalisation in South Korea-which led to foreign capital inflows in the 1990s-and applied the Keynesian general equilibrium model to explain how the appreciation of nominal exchange rates accompanied by capital inflows influenced the relative price of tradable and non-tradable goods. They found that although the real interest rate was very high because of tight monetary policies, optimistic expectations towards the real estate market offset the effort to restrict the money supply, in the end leading to real estate bubbles.

The common point in these articles is that a real estate bubble results from huge capital inflows, which alter the nominal exchange rate and the domestic price level, distorting the real exchange rate. In the case of the Chinese economy, however, we argue that even if the nominal exchange rate does not change and the capital account remains strictly regulated, real estate bubbles can occur, as long as foreign reserves driven by exports keep growing and the financial system is underdeveloped. Collyns and Senhadji (2002) found in the empirical analysis of the East Asian financial crisis that foreign investors' over-optimism and the fragile financial system caused bubbles in stock markets and real estate markets. This research is also a reflection of the opening of the capital account in a vulnerable financial system. Still, the above research on the fragility of financial systems cannot explain why bubbles occur only in real estate markets without the opening of the capital account in countries such as China (Ogawa and Sun 2001), while our paper validates the relationship between excessive monetary liquidity and real estate bubbles in China's economy, based on our theoretical model about private saving and investment behaviour and related empirical analysis.

Real estate bubbles are complex that scholars have not yet achieved agreement on their causes, features and influences (Hunter et al. 2005). ${ }^{3}$ Accordingly, there are conflicting policy suggestions (Meltzer 2003; Trichet 2005; Roubini 2006). In this chapter, we are not so ambitious as to explore a complete set of related economic indices or an integrated one affecting real estate bubbles. In this sense, monetary liquidity is just one of many important factors causing real estate bubbles and our research is complementary to other research in this field. The index of excessive monetary liquidity, however, 
emphasises the effect of imbalances in the economic structure on real estate bubbles, which has not been studied systematically before. On the other hand, many factors revealed by previous research explaining bubbles are related to excessive monetary liquidity, such as money illusion (Brunnermeier and Juilliard 2006), incomplete information (Morris and Shin 2002; Favara and Song 2006), inelastic house supply (Gyourko et al. 2006), buyer optimism (Herring and Wachter 2005; Case et al. 2003) and incomplete financial markets (Stein 1995; Ortalo-Magne and Rady 2006).

To fully reflect the influence of structural excessive monetary liquidity on real estate bubbles, we make several improvements on the existing literature. First, we find that excessive monetary liquidity results from twin surpluses (the capital account and the current account) in the balance of payments under the rigid exchange rate system, rather than from expanding monetary policies, which is derived from fundamental principles of open macroeconomics and related macroeconomic indices commonly accepted by scholars (Calvo et al. 1993; Agénor and Montiel 1999). Second, excessive consumer savings will lead to over-investment in bubble assets in an incomplete financial market where bubbles are expected, according to the OLG model for private savings and investment behaviour (Caballero and Krishnamurthy 2005). Third, we select bank deposits as the index for excessive monetary liquidity rather than bank loans (used by previous researchers), based on the phenomenon that savings accompanied by the growth of foreign reserve increase rapidly and banks overinvest in real estate assets. Last but not least, we create an index for liquidity spillover effects to identify the influence of liquidity differences on real estate bubbles across provinces.

Our research shows that in the case of real estate bubbles in contemporary China, the savings index is statistically more significant than the loan index, which manifests the structural excessive monetary liquidity to be an indispensable reason behind real estate bubbles. Therefore, our suggestion of a radical approach to appeasing the surge of real estate bubbles in China is to solve the structural imbalance in the Chinese economy-specifically, the conflict between the expansion of trade and the fragility of financial systems.

\section{The externally dependent economy and excessive monetary liquidity}

China's rapidly growing economy has the following features: extensive fixed investment (I) grows rapidly; domestic demand led by individual consumption (C) remains mild; while at the same time, residential disposable incomes keep increasing and private savings (S) in banks grow proportionally ${ }^{4}$ (Figure 17.1 and 


\section{Figure 17.1 Growth rate of residents' savings, 1995-2006}

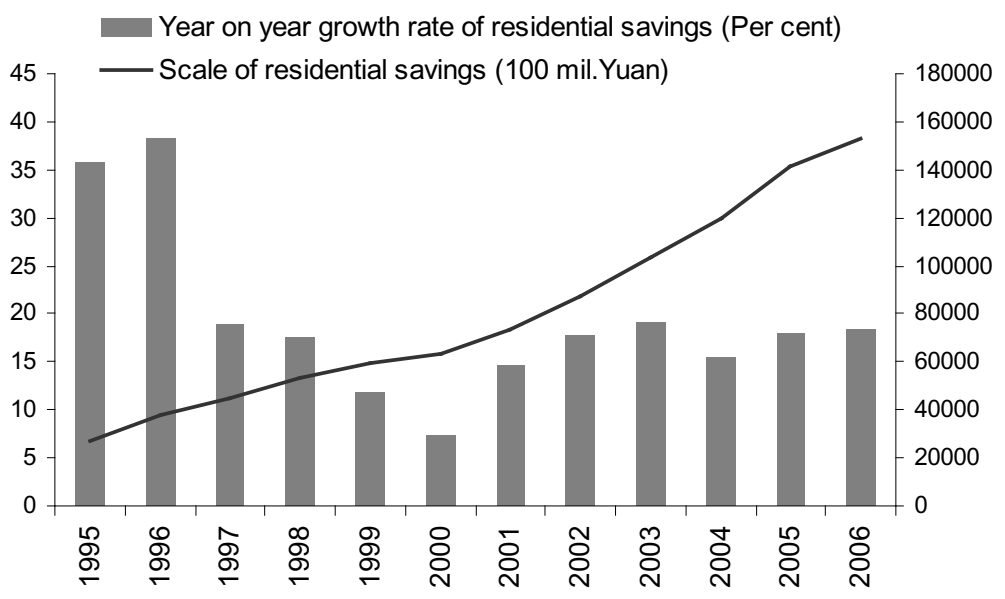

Source: China Wind Database.

People's Bank of China 2006). That is, investment in China is surplus compared with domestic consumption but insufficient compared with domestic savings since $S-I>0$. Third, though net exports (EX-IM) are increasing substantially, the scale is still limited. China's gross exports account for more than 60 per cent of GDP, which is much larger than the figure the United States and Japan (the ratio of net exports to GDP is a commonly used index for the external dependence of an economy). Most exports are of manufactured products, a high proportion of which are from foreign-owned enterprises (Figure 2). The increase in exports is accompanied by the importation of high value-added intermediate goods (IM). ${ }^{5}$ The last characteristic is that the Chinese government's fiscal policy tends to be conservative $(T>G)$.

From a basic principle of open macroeconomics, the combination of superfluous domestic savings and conservative fiscal policy will lead to a trade surplus.

$$
(S-I)+(T-G) \equiv(E X-I M)
$$


In fact, with the persistently fast-growing Chinese economy and the increasingly externally dependent economic structure accompanying that growth (dependent on exports and foreign direct investment), the twin surpluses in the balance of payments are inevitable. Therefore, with a stable exchange rate, ${ }^{6}$ a lasting surplus in the current account (CA), led by a trade surplus (EX-IM), and the capital account (KA). led by foreign direct investment (FDI), trigger increases in foreign reserves, recently in China, to historical heights (see Equation 2 and Figure 17.2).

$$
C A+K A \equiv R E
$$

Excessive liquidity (uncontrollable increase in monetary supply, M) resulting from the expanding foreign reserve will restrain the 'miracle' of lasting rapid economic growth in an externally dependent economic structure. In order to maintain the price competitiveness of domestic enterprises, the central bank has to implement contractive monetary policies ${ }^{7}$ (we define a contractive monetary policy as forcibly lowering domestic credit, DC, to stabilise monetary supply, M) ${ }^{8}$ (see Figure 17.3). ${ }^{9}$

Figure 17.2 Twin surplus of balance of payments, 1990-2005

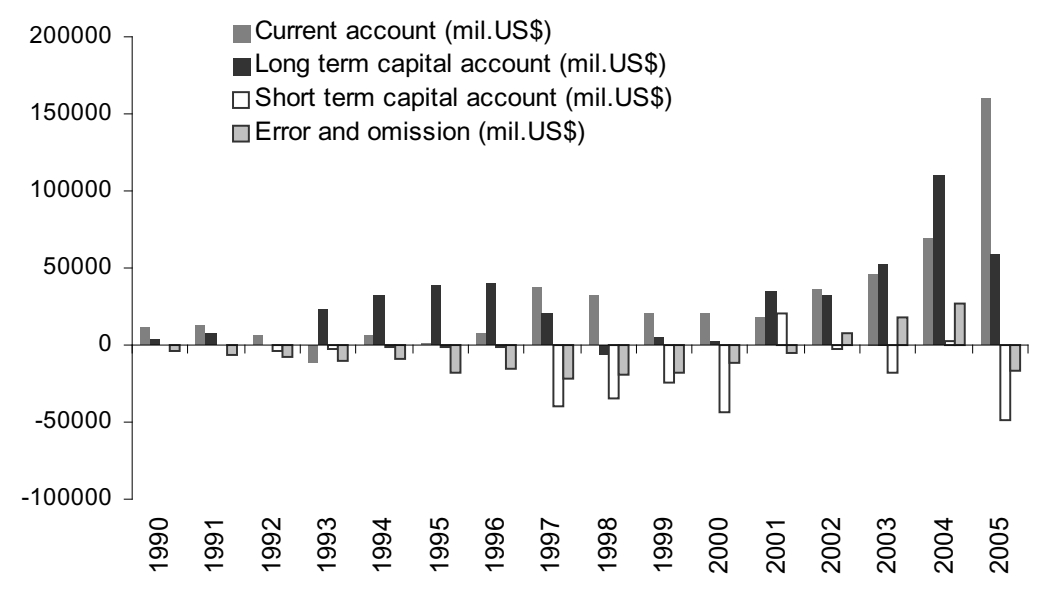

Source: China Wind Database. 
Figure 17.3 Comparison of growth rates of M1, M2 and bank loans, 2001-2006 (per cent)

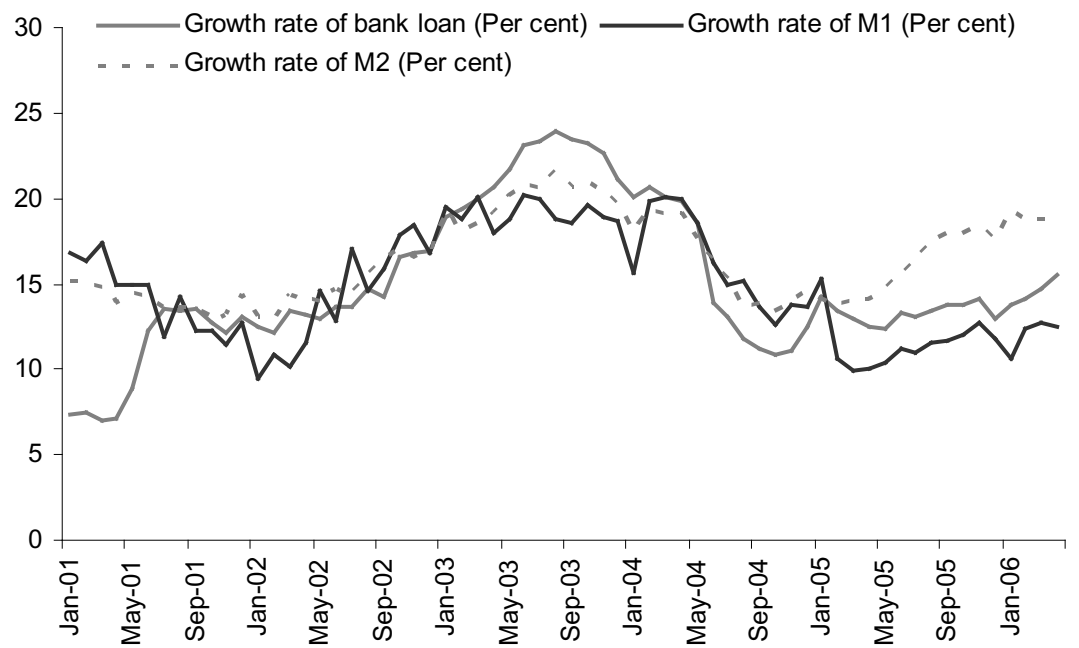

Source: China Wind Database.

\section{Figure 17.4 Growth rate of real estate prices, 1999-2005 (per cent)}

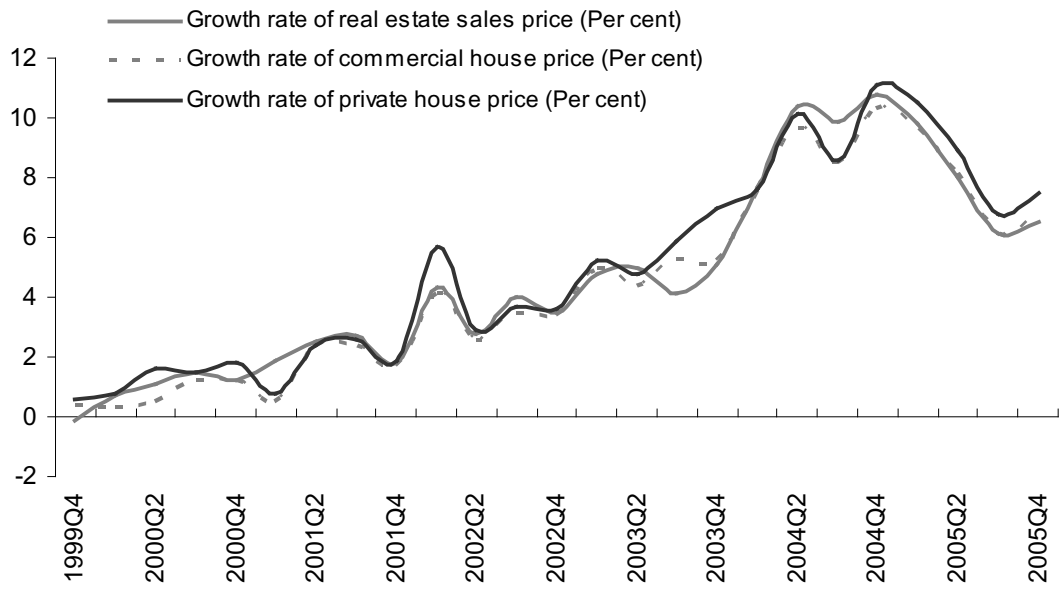

Source: China Wind Database. 
Specifically, we employ the equation of the central bank's balance sheet to show the mechanism of money supply

$$
M \equiv D C+R E
$$

Although the combination of tight monetary policy, persistently growing fixed investment and the over-saving behaviour of consumers effectively relieve the pressure of inflation in the commodity market, the fragile banking system is facing the challenge of excessive monetary liquidity (Figure 17.3). For instance, confined by the macro control policy and institutional restrictions, banks cannot freely expand loans to enterprises and adjust deposit and credit interest rates. Hence, the boosting of deposits (see Figure 17.1 and M2 in Figure 17.3) worsens the imbalance on commercial banks' balance sheets.

Once banks try to balance their balance sheets, they have to pursue high-return assets ${ }^{10}$ such as real estate loans. On the demand side, Chinese consumers have to suppress current consumption and save most of their increasing income in banks in order to invest in safe and increasingly valuable assets $^{11}$ for future health insurance, pensions, educational expenditure and unemployment insurance. The expanding supply and demand of liquidity can boost real estate prices (see Figure 17.4).12

It is the externally dependent economic structure (export dependent and FDI dependent) that brings excessive monetary liquidity (private savings or $\mathrm{M} 2$ ), rather than relaxed monetary policy (the inflation of M1 or DC), as in industrialised countries. Will excessive monetary liquidity from externally dependent economic structures cause real estate bubbles, as the relaxed monetary policy does in industrialised countries? What is the mechanism for and features of it? We will answer these questions through formal theoretical models in the next section.

\section{A simple OLG model}

We use an OLG model ${ }^{13}$ to analyse the inherent connection between the externally dependent economy and real estate bubbles. We note the coexistence of a lack of social security, lagged development of financial systems and fast growth of private savings in China. Muth (1961), Brock (1975) and Gaber (1990) set up the rational bubble mechanism. The pioneering paper of Tirole (1985) introduced the rational bubble mechanism into the OLG model to study asset price bubbles, which shows that in a dynamically inefficient economy with excessive capital accumulation, rational bubbles would reduce the excessive capital accumulation and thus realise Pareto's improvement. ${ }^{14}$ The model of 
Caballero and Krishnamurthy (2005), however, and our paper suggest that in an externally dependent (dynamically inefficient) economy, the rational bubble could lower social welfare ${ }^{15}$ by a credit crunch in the banking system when bubbles burst, although it could stimulate enterprises to expand their production when the real estate market booms. While Caballero and Krishnamurthy (2005) focus on economies dependent on foreign debt, we focus on economies depending on exports and FDI growth, which is the case in China. So, we believe that our model can better explain the story behind excessive monetary liquidity and real estate bubbles in the Chinese economy.

\section{Model set up}

First, we assume an externally dependent economy of two overlapping generations. Specifically, the young generation born at the beginning of period ' $t$ ' works in foreign enterprises that are export oriented and grow at a constant rate ' $\mathrm{g}$ '. For precautionary incentives mentioned above, the young generation saves all its income, $F_{t}$, in the form of foreign savings or investment in the real estate market (the only two instruments with safe and high returns) in order to get high and smoothed income. The total assets of the old generation in period $\mathrm{t}+1$ amounts to $F_{t+1, t}$ (measured by foreign currency), which the old generation uses either to produce as entrepreneurs or to fund entrepreneurs' production as bankers. ${ }^{16}$ For simplification, income from the old generation's career will cover the consumption of the whole society. In addition, the fixed asset $K_{t}$ owned by the old generation will be bequeathed to the young generation.

Obviously, income difference between the young generation in period ' $t$ ' and period $\mathrm{t}+1$ is determined by the growth rate of exports, since the young all work in export-oriented enterprises:

$$
F_{t+1}=(1+g) F_{t}
$$

If the young generation invests $\delta$ part of their income in the real estate market and the annual return of real estate investment is $\tilde{r}^{b}$ (a stochastic variable), then the total foreign asset $s^{17}$ of the old generation in period $t+1$, accumulated from period ' $t$ ', when they are young, is

$$
\tilde{F}_{t+1, t}=F_{t}\left[\delta\left(1+\tilde{r}^{b}\right)+(1-\delta)\left(1+r^{*}\right)\right]
$$

Furthermore, the old-generation entrepreneurs collateralise their fixed assets, $K_{t}$, to borrow banks' fixed assets for manufacturing and use their foreign assets (marked as $\tilde{F}_{t+1, t}$ ) to import raw materials from abroad. The rates 
should be above one, denoted as $R$ and $\tilde{r}_{t+1}^{B L}$ respectively. All funds are utilised to manufacture domestic non-durable products, which in turn brings a return of ' $R$ ' per unit of investment. (' $R$ ' is determined exogenously by productivity.) Therefore, the ex post trade surplus at period ' $\mathrm{t}$ ' is equal to the exports of the young generation minus the imports of the old generation,

$$
F_{t+1}-F_{t+1, t}=\left[\left(g-r^{*}\right)-\delta\left(r^{b}-r^{*}\right)\right] F_{\mathrm{t}}
$$

Namely, the trade surplus increases with the growth rate of exports, while it decreases with the investment scale and return in the real estate market.

With the equilibrium of the credit market, banks' maximum lending should be equal to entrepreneurs' maximum borrowings,

$$
\tilde{F}_{t+1, t}=\frac{\rho R}{\tilde{r}_{t+1}^{B L}} K_{t}
$$

in which $\rho$ is the valuation coefficient for the collateralised fixed assets given by banks ( $\rho$ is a positive number, usually smaller than one, since banks will not lend as much as the collateralised value). Entrepreneurial value is determined by production technology, return on investment and capital cost, so the return is

$$
R K_{t}+R \tilde{F}_{t+1, t}+\left(R-\tilde{r}_{t+1}^{B L}\right) \frac{\rho R}{\tilde{r}_{t+1}^{B L}} K_{t}
$$

Banks' profits are from rent of their real estate and interest from lending so they will receive at the end of period $t+1$

$$
R K_{t}+\tilde{F}_{t+1, t} \tilde{r}_{t+1}^{B L}
$$

Since the probability for the young generation to become bankers or entrepreneurs is fifty-fifty, the young will choose their house investment ratio to maximise their expected incomes in the future,

$$
\max _{0 \leq \delta \leq 1} E_{t}\left\{R K_{t}+\tilde{F}_{t+1, t} \frac{R+\tilde{r}_{t+1}}{2}+\frac{R-\tilde{r}_{t+1}}{2} \times \frac{\rho R}{\tilde{r}_{t+1}} K_{t}\right\}
$$

Second, regarding the mechanism of bubbles in the real estate market, we assume that the intrinsic value of real estate is zero. This simplification focuses our attention on the 'bubble side' of the real estate market. Since the intrinsic 
value of real estate is stable when bubbles emerge in the market, we believe this simplification to be reasonable. When the young generation in period ' $t$ ' believes that the purchased real estate can be sold to the next generation at a higher price, speculation will prevail and the self-fulfilling rational bubble will come into existence. In this setting, the growth rate of real estate prices is determined by the growth rate of the young generation's earnings and exports. More specifically, $r^{b}=g$, in which $r^{b}$ represents the growth rate of real estate prices.

In this model, we see that the 'structural' twin surpluses of the balance of payments (see Equations 1, 2) bring about excessive liquidity, which in turn forms bubbles in the real estate market. The young will sell their assets in advance altogether ${ }^{18}$ only when external shock forces bubbles to expand too rapidly $\left(r^{b}>g\right)$. So people begin to consider that income growth cannot sustain the bubbles and the bubble bursts because of their selling action. If the probability of a bubble burst is $\pi$, then the expected return of real estate investment $\left(\hat{r}^{b}\right)$ is

$$
1+\hat{r}^{b}=(1-\pi)(1+g)
$$

Since we focus on consumers' motivation for real estate investment and the corresponding real estate bubble, we assume the expected return of real estate investment to be always greater than foreign savings,

$$
\hat{r}^{b}-r^{*}=(1-\pi)\left(g-r^{*}\right)-\pi\left(1+r^{*}\right)>0
$$

In addition, the movement of real estate prices could influence the loan supply and demand in the credit market (see Equations 5,7), which in turn influences banks' lending rates. Therefore, during the bubble economy, the lending scale is $F_{t+1, t}^{B}=\left[1+r^{*}+\delta\left(g-r^{*}\right)\right] F_{t}$ and the loan rate is $\tilde{r}_{t+1}^{B L}=r_{t+1}^{B}$; when the bubble has burst, the lending scale will be $F_{t+1, t}^{C}=\left(1+r^{*}\right)(1-\delta) F_{t}$, with the lending rate assumed to be $\tilde{r}_{t+1}^{B L}=r_{t+1}^{C} \cdot{ }^{19}$

\section{The optimal portfolio allocation of the young generation}

The first order condition of the optimisation problem (Equation 10) is

$$
(1-\pi) \frac{g-r^{*}}{1+r^{*}}\left(R+r_{t+1}^{B}\right)-\pi\left(R+r_{t+1}^{C}\right)=0
$$

The optimal allocation parameter, $\delta$, does not appear in the first order condition. The economic meaning is that as long as the lending rates $\left(r_{t+1}^{B}\right.$ and $r_{t+1}^{C}$ ) under the condition of a sustained bubble and bubble collapse are 
determined in advance by the young generation, they can always maximise their expected income and they are indifferent about the portfolio allocation, since the potential loss (return $=-1$ ) of the bubble collapse (the probability is $\pi$ ) is always offset by the potential gain $\left(g-r^{*}\right)$ of the bubble sustaining (the probability is $1-\pi)$. Here, $\left(R+r_{t+1}^{B}\right)$ is the normal return of banks in a bubblesustaining period and $\left(R+r_{t+1}^{C}\right)$ in a bubble-burst period.

On the other hand, we need to make sure that the credit market is clear. Utilising the equilibrium of the credit market (Equation 7), we can get the equilibrium lending rate when bubbles are sustained

$$
r_{t+1}^{B}=\max \left\{1, \frac{\rho R}{1+r^{*}+\delta\left(g-r^{*}\right)}\right\}
$$

For simplification, we let $F_{t}=K_{t}$, and assume that $\rho R<1 .{ }^{20}$ Obviously, $r_{t+1}^{B}=1$ means that the savings in the young generation are so abundant that supply of loans of the old generation forces the lending rate to the bottom line.

Likewise, the lending rate when bubbles burst is

$$
r_{t+1}^{C}=\max \left\{1, \min \left[\frac{\rho R}{\left(1+r^{*}\right)(1-\delta)}, R\right]\right\}
$$

The equation means that when bubbles burst, the savings of the young generation contract, as does the lending of the old generation. Therefore, the lending rate rises. Of course, the lending rate should be no smaller than one and no greater than the return of production ' $\mathrm{R}$ '.

Using the first order condition (Equation 13), together with $r_{t+1}^{B}=1$ (and Equation 15), we can get the ex ante optimal portfolio allocation $\left(\delta^{*}\right){ }^{21}$

According to the individual optimal portfolio allocation, we can confirm the conclusion of existing references in the introduction that bubbles do stimulate real investment. The increase of real investment does not, however, necessarily justify the allocation. In the next section, we will judge the appropriateness of the optimal allocation, $\delta^{*}$, according to its influence on social welfare.

Evaluation of social welfare and over-investment in the real estate market

Since the asset value of the young generation is elevated in a bubble economy, the values of the entrepreneurs' capital and the banks' loan scale both increase. The total social output is

$$
Q^{B}=\frac{R+1}{2} F_{t}\left[1+r^{*}+\delta\left(g-r^{*}\right)\right]+\frac{1}{2}(R-1) \rho R K_{t}+R K_{t}
$$


There would, however, be two possibilities when bubbles burst. The first is that without credit crunch, featured by $r_{t+1}^{C}=1$, the total social output is

$$
Q^{C, S}=\frac{R+1}{2} F_{t}\left(1+r^{*}\right)(1-\delta)+\frac{1}{2}(R-1) \rho R K_{t}+R K_{t}
$$

The second is that with credit crunch, featured by $r_{t+1}^{C}>1$, the total social output is

$$
Q^{C, L}=R F_{t}\left(1+r^{*}\right)(1-\delta)+R K_{t}
$$

Comparing the three equations on aggregate output, we find that bubbles have two effects. One is to stimulate production (Equation 16); the other is to restrain production (Equations 17 and 18). Therefore, the government will maximise the expected social output taking both effects into account. Notice that the objective function of social welfare is different from that of individual expected income:

$$
\max _{0 \leq \delta \leq 1} \pi Q^{C}+(1-\pi) Q^{B}
$$

here $Q^{C}=Q^{C, S}$ or $Q^{C}=Q^{C, L}$. Then we could obtain

$$
F_{t}\left(\frac{R+1}{2}\right)\left[(1-\pi)\left(g-r^{*}\right)-\pi\left(1+r^{*}\right)\right]>0, \text { where } r_{t+1}^{C}=1
$$

or

$$
(1-\pi)(R+1) \frac{g-r^{*}}{1+r^{*}}-2 \pi R<0, \text { where } r_{t+1}^{C}>1
$$

The first order conditions do not hold and we get the corner solution. For the first inequality, the model has assumed that the expected return of bubble assets is greater than the foreign deposit rate. To the other inequality, since this is when the loss of social output reaches its maximum, the inequality is still acceptable. Besides, bank credit rates are rigid in the two extreme points, which indicates that the increase of real estate investment ratios does not affect the lending rate in the two extreme points, but the real estate investment ratio has a positive monotonic correlation with the credit rate in the middle area. If we denote $\delta^{S}$ and $\delta^{L}$ as the critical values for the conditions of 'middle term $=1$ '22 and 'middle term $=R$ ' respectively, we can conclude (see Equations 19 and 20) that the government's optimal preference investment ratio, $\delta^{G}$, is always $\delta^{S}$ in 
both conditions. As well, $\delta^{G}$ is always lower than the individual optimal ratio, $\delta^{*}$. This means that individual investment in the real estate market is speculative and, from the perspective of social welfare, individual rational investment in real estate markets is excessive.

$$
\delta^{G}=\delta^{S}<\delta^{*}
$$

In short, the model demonstrates that with an incomplete financial market, the excessive monetary liquidity brought about by export increases will be transformed into individual motivation to invest in the real estate market, resulting in rational or speculative bubbles. From the viewpoint of social welfare, the investment is excessive. Following the stylised fact and the OLG model, quantitative analysis will be given below.

\section{Data, variable selection and empirical modelling}

This section intends to answer quantitatively two important questions. Is excessive monetary liquidity is the main contributor to real estate bubbles in China? Is there speculative investment in the real estate market?

We adopt panel data analysis based on the regional data from 28 provinces $^{23}$ in China rather than the time-series analysis using macroeconomic data. This is because excessive monetary liquidity is a new phenomenon that has emerged only in recent years. ${ }^{24}$ Therefore, the time-series analysis cannot identify the bubble for lack of sufficient data (Kalra et al. 2000).

The cross-provincial panel data in this chapter are from February 2004 to December 2005. Even if year-on-year adjustment is conducted to ensure the consistency of empirical analysis with the theoretical model, and to relieve the problem of the time-series characteristic, each variable still has as many as 308 observations. We further study the ripple effect (Cameron et al. 2006), that is, to introduce the spillover liquidity variable in order to discuss the influence of cross-provincial liquidity differences on local real estate prices. It is an important criterion of speculative investment (the second issue to be tested) uncovered by the stylised fact and the theoretical model of whether the ripple effect is statistically significant. ${ }^{25}$

Since we want to examine the real estate bubble resulting from the externally dependent economy, we use the difference between the growth rate of real estate prices in China minus the short-term US bond rate as the dependent variable in our empirical model, according to the theoretical model (see Equation 12). As real estate prices are not obtainable directly, we calculate the prices from the division of the sales revenue and the sale price of commercial houses. 
When selecting independent variables, we choose the growth rate of savings, ${ }^{26}$ rather that of bank loans or monetary supply, because we want to emphasise the role of monetary liquidity. In fact, banks are regulated with respect to the ratio of deposits to loans during the sample period; the scale of loans is therefore determined by that of savings. And the down payments of individuals and the autonomous lending of enterprises, while not included in credit variables, are reflected in savings. So, the growth rate of savings can better illustrate real estate bubbles.

The spillover effect variables are measured by the difference between the growth rate of local savings and aggregate savings. This index can examine whether capital will flow from capital-rich areas to capital-deficient areas. Such capital flow will promote real estate bubbles in capital-deficient areas. With cross-provincial capital flows, the growth rate of real estate prices all over China could tend to converge. As for other independent variables that need to be controlled, we choose variables according to the survey on empirical works about real estate bubbles (Cameron et al. 2006) and the availability of Chinese data. Specifically, these variables are the growth rate of residential income, enterprise profits, losses of loss-making enterprises and land prices. ${ }^{27}$ Residential income and enterprise profits can reflect fundamentals of the economy, but can also control the influence of cross-provincial differences of economic development on real estate prices. The inclusion of the variable of losses of loss-making enterprises follows a new argument that enterprises with low productivity and profitability tend to speculate in the real estate market (Ventura 2004). Construction cost is also a fundamental factor that cannot be omitted. But since the regional data for this variable are not accessible, we use land price as its index. Land prices were found in the same way as the real estate price.

Therefore, the panel data model we employ is

[the rate of change in real estate price after adjustment $]_{i t}=$

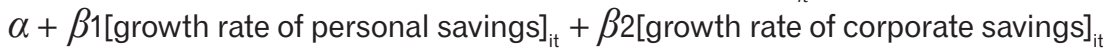

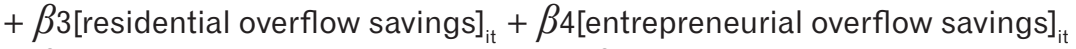

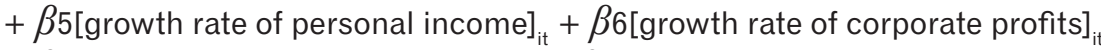

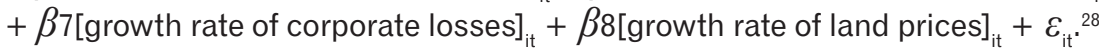

For each variable in the model, we examine its characteristics, from which we can intuit the influence of excessive monetary liquidity on real estate bubbles (not tabulated). 
Most of the monthly data in this chapter are from the China Wind Database and data about provincial savings are from Statistics Monthly, published by the People's Bank of China. All variables are adjusted to eliminate seasonal effects (the year-on-year growth rate) as well as inflation (adjusted by the consumer price index). The US interest rate is adjusted by the US Consumer Price Index. ${ }^{29}$

\section{Results of empirical analysis}

Table 17.1 shows the estimation of the empirical model of panel data discussed above. Models 1 and 2 are analysed in order to test the robustness of the general Model 3, especially for the significance of the indices for excessive monetary liquidity. In Model 1, we consider only the impact of the scale of savings on real estate prices. Model 2 further examines the spillover effect of excessive monetary liquidity.

Obviously, whether in the general model or the simplified models, the growth of local savings (monetary liquidity) also has a positive influence on the real estate price. In the sample period we selected, the monetary liquidity of local enterprises has a larger influence on the real estate price. Interestingly, after controlling the liquidity indices, although the sign of the estimated parameters of the growth rates of residential income, land prices and enterprise profits are consistent with the general economic principles, none are statistically significant. For the growth rate of losses of loss-making enterprises, the parameter is also insignificant and even the sign of the parameter is incorrect. ${ }^{30}$ Therefore, the excessive monetary liquidity is probably the dominant factor supporting real estate bubbles. This result answers the first question raised at the beginning of the previous section.

As for the spillover effect indices, only the enterprise savings spillover variable has a significant effect on real estate prices, while the residential savings spillover variable does not contribute to the bubbles. ${ }^{31}$ This result confirms the speculative behaviour of enterprises in the real estate market since we believe the cross-regional capital flows are, to a large extent, speculative. Thus, we have answered the second question.

The constant is significant, which shows that those important variables we put into the constant do have influence over real estate bubbles. Since we use growth rates for all the variables in the regression, the determinant coefficient ( $R$ square) is relatively low.

In order to ensure the precision of the panel data analysis method, we apply the Breusch-Pagan LM Test and the Hausman Test to the sample (see Table 


\section{Table 17.1 Estimation of random effect ${ }^{a, b}$}

Dependent variable: housing price adjusted

Explanatory variable (all in annual growth rate)

Residential savings

Enterprise savings

Residential savings spillover effect

Enterprise savings spillover effect

Residential income

Land price

Enterprise profit

Losses of loss-making enterprises

Constant

R-squared overall

Number of observables

Rho (fraction of variance due to $u_{-} i$ )
Model 1

Model 2

Model 3

$0.487 * * *$
$(0.174)$
$1.709 * * *$
$(0.212)$

$1.284 * * *$

$1.263 * * *$

(0.348)

(0.368)

$2.075^{* * *}$

$2.179 * * *$

$(0.501)$

(0.493)

0.226

(0.542)

(0.554)

$1.727 * * *$

$1.839 * * *$

(0.518)

(0.525)

0.048

(0.110)

0.023

(0.017)

0.003

(0.043)

$-0.015$

(0.031)

$-0.137 * * *$
$(0.034)$
0.1588
308
0.539

$-0.274^{* * *}$

$-0.285^{* * *}$

(0.051)

0.2049

308

0.561

\section{Notes: * $p<0.10 \quad * * p<0.05 \quad * * * p<0.01$}

a Stata is employed to perform the panel data analysis. The number in parentheses '()' represents the standard error of the estimation.

b Since in Breusch-Pagan's LM Test, Chi-sq(27) = 90.23988, P-value = 9.7e-09;

heteroskedasticity in group OLS regression is phenomenal so that it is necessary to use panel data models. Furthermore, in the Hausman Test, Chi-sq(8) $=2.06$, P-value $=0.9790$, which means that the null hypothesis of no correlation between the fixed term and independent variables cannot be rejected. Therefore, we use random-effect models in our estimations.

Source: Authors' calculations. 
17.1). From the random effect model employed, we can see that the regional characteristics of real estate price growth is not fixed, which could be a result of the overflow effect of monetary liquidity.

\section{Conclusions}

First, we argue that an externally dependent economy with structural imbalances characterised by twin surpluses can, for example, bring about excessive monetary liquidity under a rigid exchange rate system. Excessive liquidity of this kind is distinctly different from that of the standard case in which excessive liquidity is the result of a kind of loose monetary policy aimed at combating economic slowing or depression.

Second, we extend C-K's saving-investment model to uncover that excessive monetary liquidity can incur rational bubbles in real estate markets in an economy such as China's, where its financial market has not been well established. Under these circumstances, people tend to speculate in the real estate market out of the precautionary savings motivations of smoothing their income. This mechanism is not covered in the current literature about Chinese real estate bubbles (Wang 2005; Yi 2005). The existing studies of the influence of excessive monetary liquidity on real estate prices have not paid enough attention to the relevant effect of the externally dependent economic structure on real estate bubbles.

Third, we select savings and spillover variables of savings to test the mechanism of real estate bubbles introduced by basic macroeconomic principles and the OLG model. Through panel data analysis of 28 provinces, we found that the current real estate bubble in China is caused mainly by the externally dependent economic structure, which results in excessive monetary liquidity. Enterprise savings and their spillover effect play more important roles than their residential counterparts.

Based on the above results, our policy suggestion to solve the problem of excessive monetary liquidity is that, in the short term, the government should intensify fiscal and monetary restraint on speculative real estate investment (for example, to increase the capital adequacy ratio of the banks and raise taxes on real estate investments). This will modify individuals' rational expectations of the surge of real estate prices: in the long term, the government should change the current rigid exchange rate system, develop Chinese financial markets, improve the social security system and adjust the dependence of growth on expansion of net exports. ${ }^{32}$ 


\section{Notes}

1 There has been much research on the issue of real estate bubbles recently. Some excellent surveys are included in Hunter et al. (2005). Most focuses on the following aspects: the causes and measurement of real estate bubbles, their impact on the real economy and government supervision and regulation of real estate investment. Some excellent surveys are included in Hunter et al. 2005.

2 Investigations of housing reform and relative questions on the late 1990s could take Zhou 2003 and Sato 2006 as references. It is obvious that the abundance of individuals involved in real estate speculation nowadays is a consequence of government-distributed affordable housing in the early reform period.

3 Kindleberger (1987) defined asset bubbles this way: '[a] sharp rise in price of an asset or a range of assets in a continuous process, with the initial rise generating expectations of further rises and attracting new buyers-generally speculators interested in profits from trading rather than in its use or earning capacity. The rise is then followed by a reversal of expectations and a sharp decline in price, often resulting in severe financial crisis—in short, the bubble bursts.'

4 Recently, enterprise savings have been increasing gradually, because profits are declining and the renminbi is expected to appreciate.

5 Though the contribution of net exports to GDP is low, processing-trade enterprises absorb numerous low-paid workers and exports help relieve the deflationary pressure from the growth of production capacity.

6 If the price-adjusting monetary policy is effective, exchange rate adjustment can inhibit excessive monetary liquidity better than the contractive monetary policy in the current situation of the twin surpluses. Due to the fragility of the Chinese financial system, however, and the externally dependent economy, the central bank cannot actively employ price-adjusting policies (Mckinnon 2005 and Frankel 2004).

7 The inflation pressure triggered by excessive monetary liquidity could intensify polarisation between the rich and the poor.

8 The central bank also actively applied the sterilised monetary policy in the foreign exchange market from 2003 to 2005, although the intervention was weak compared with the surges of capital inflows. The government's burden will, however, become large if sterilisation is used for a long time.

9 M1 stands for cash and demand deposit, M2 includes saving deposit and M1. Figure 17.3 shows clearly the central bank's sterilised monetary intervention.

10 In circumstances of interest rate regulation, banks have no right to lower the savings interest rate. Even if banks can, most people could also put excessive liquidity into the banking system for real estate investment with safe and higher returns.

11 In this paper, assets with safe and higher returns refer to assets with rational bubbles. Currently in China, bubbles occur most easily in those assets well supported by government policies and by optimistic expectations in the market. As long as the market believes the boom is sustainable, safe and higher returns will persist. Real estate bubbles in contemporary China illustrate the mechanism.

12 From Figure 17.4, the price decline from 2005 is due to stricter regulation by the government on the entrance of foreign capital into the real estate market. Therefore, some foreign hot 
money left this market, which is consistent with the phenomenon of hot money flight from China as displayed in Figure 17.2, which shows negative net short-term capital inflow. This positive correlation between monetary liquidity and real estate prices is in accordance with our theory and empirical results.

13 Blanchard and Fischer (1989) covered various theoretical mechanisms of OLG models using three chapters in Lectures on Macroeconomics. Ljungqvist and Sargent (2004) explain the application of OLG in the second edition of the famous Recursive Macroeconomics Theory. There are also some classical papers on OLG models. For instance, we can categorise OLG models according to asset attributes into the following types: the OLG model with money (Samuelson 1958); with corporate bonds (Diamond 1965); with corporate bonds and bubble assets (Tirole 1985); with equity and corporate bonds (Abel et al. 1989); with government bonds (Barro 1973); and with pension funds (Diamond and Mirrlees 1978).

14 Blanchard and Watson 1982, Weil 1987 and Ventura 2004 also value bubbles positively.

15 King and Ferguson 1993, Saint-Paul 1992 and Grossman and Yanagawa 1993, while studying economic growth, point out that bubbles can also occur in a dynamically efficient economy, which could lower the investment ratio in real capital, and technology advancement slows down accordingly. Thus, economic growth is hampered and social welfare declines.

16 Such a set up is to emphasise 'investment' instead of 'consumption'. Adding consumption behaviour into the model, such as done by Tirole (1985), will not change the result of our paper.

17 We assume that the fixed exchange rate is one for simplicity and domestic currency is convertible through the current account.

18 The fall of real estate prices in 2005 in China cannot be interpreted as a burst of bubbles; it was just a temporary effect of macro control policies (currently, $r^{b}<g$ ).

19 Although the lending rate is rigid, credit rationing is popular in China. In this sense, the latent lending rate is changing.

20 Lacking efficient credit risk management, banks in emerging markets would greatly discount collateral assets.

21 There are two extreme situations. If $r_{t+1}^{C}=1$, according to Equation 12,

$$
(1-\pi) \frac{g-r^{*}}{1+r^{*}}(R+1)-\pi(R+1)>0
$$

The optimal investment ratio should be ${ }^{*}=1$, that is, to put their whole income in the real estate market. On the contrary, if $r_{t+1}^{C}=R$ and when

$$
(1-\delta)\left(g-r^{*}\right)-\delta\left(1+r^{*}\right) \frac{2 R}{1+R}<0
$$

dumping all real estate assets would be the optimal choice-in other words, $\delta *=0$. The credit market, however, is not clear in these two situations, so these two solutions do not hold.

22 The middle term equals

$$
r_{t+1}^{C}=\frac{\rho R}{\left(1+r^{*}\right)(1-\delta)}
$$

23 The following provinces and cities are included: Beijing, Tianjin, Hebei, Shanxi, Neimengu, Liaoning, Jilin, Heilongjiang, Shanghai, Jiangsu, Zhejiang, Anhui, Fujian, Jiangxi, Shandong, Henan, Hubei, Hunan, Guangdong, Guangxi, Hainan, Chongqing, Sichuan, Guizhou, Yunnan, Shanxi, Gansu and Ningxia. 
24 The reform of housing markets in China started less than 10 years ago. Time-series data of real estate prices are very limited.

25 Since data about the asset allocation variable in the theoretical model are unavailable, we use the spillover variable as the proxy for the portfolio allocation to see if there is speculative behaviour.

26 Data on the renminbi counterpart of foreign reserves are not accessible as required by our theoretical model.

27 There are some other import-control variables, such as demographic structure, the population growth rate, bank mortgage rates, the stock of real estate and the portfolio allocation to securities. Monthly provincial data of these variables are not available, so we put them into the constant because we assume that these variables are relatively stable in the short term.

$28 \varepsilon_{i t}=k_{i}+u_{i t}: i$ represents the cross-sectional information, $t$ represents time, $k$ is the fixed effect. The Hausman Test will be conducted to determine which of the two effects-fixed and random-is relevant for our panel data analysis (Hsiao 2003).

29 We abandon the data from Qinghai, Xinjiang and Xizang because of its incompleteness. For two missing observations of the land price and residential income, we use smoothing modification.

30 The reason for insignificance of residential income is that people can easily access the speculative real estate market by borrowing to cover the down payment. Similar mechanisms can explain the insignificance of enterprise profits and losses of loss-making enterprises. Even if land prices can affect real estate prices, a transaction cannot be reached without enough liquidity. Therefore, land prices are not significant after controlling monetary liquidity.

31 Such contrasts could be because individual cross-provincial investment is much more inconvenient and costly than enterprise investment, because enterprises can borrow and lend from each other freely and thus enjoy indirectly the high return of real estate investment in other areas.

32 As long as people's worries about future income persist, surplus savings will not disappear even if the renminbi appreciates and residents' disposable incomes increase.

\section{References}

Abel, A.B., Mankiw, M.G., Summers, L.H. and Zeckhauser, R.J., 1989. 'Assessing dynamic efficiency: theory and evidence', Review of Economic Studies, 56:1-20.

Agénor, P.R. and Montiel, P.J., 1999. Development Macroeconomics, Second Edition, Princeton University Press, Princeton, NJ.

Allen, F. and Gale, D., 2000. Asset price bubbles and monetary policy, Center for Financial Institutions Working Papers 01-26, Wharton School Center for Financial Institutions, University of Pennsylvania, Philadelphia.

Bank for International Settlements (BIS), 2004. 'What drives housing price dynamics: cross-country evidence', BIS Quarterly Review, March.

Barro, R.J., 1973. 'The control of politicians: an economic model', Public Choice, 14:19-41. 
Bernanke, B., 2000. 'Japanese monetary policy: a case of self-induced paralysis?', in R. Mikitani and A. Posen (eds), Japan's Financial Crisis and Its Parallels to US Experience, Institute for International Economics, Washington, DC.

Bernanke, B. and Gertler, M., 2001. 'Should central banks respond to movements in asset prices?', American Economic Review, May:253-57.

Blanchard, O.J. and Fischer, S., 1989. Lectures on Macroeconomics, MIT Press, Cambridge, MA.

Blanchard, O. and Watson, M., 1982. 'Bubbles, rational expectations, and financial markets', in P. Wachtel (ed.), Crisis in Economic and Financial Structure, Lexington Books, Lexington, UK.

Bordo, M.D. and Jeanne, O., 2002. Boom-busts in asset prices, economic instability and monetary policy, CEPR Discussion Paper 3398, Centre for Economic Policy Research, London.

Brock, W.A., 1975. 'A simple perfect foresight monetary model', Journal of Monetary Economics, 1:133-50.

Brunnermeier, M. and Julliard, C., 2006. Money illusion and house prices, Princeton and London School of Economics (unpublished).

Caballero, R.J. and Krishnamurthy, A., 2005. Bubbles and capital flow volatility: causes and risk management, Working Papers, No. 11618, National Bureau of Economic Research, Cambridge, MA.

Calvo, G.A., Leiderman, L. and Reinhart, C.M., 1993. Capital flows to Latin America: the role of external factors, Staff Papers 40(1), International Monetary Fund, Washington, DC.

Cameron, G., Muellbauer, J. and Murphy, A., 2006. Was there a British house price bubble? Evidence from a regional panel, CEPR Discussion Paper, No. 5619, Centre for Economic Policy Research, London.

Case, K.E., Quigley, J.M. and Shiller, R.J., 2003. 'Home-buyers, housing and the macroeconomy', in A. Richards and T. Robinson (eds), Asset Prices and Monetary Policy, Reserve Bank of Australia, Canberra.

China Real Estate Chamber of Commerce, 2006. 'Macro financial risk analysis of China's real estate', Economics of Trade and Finance, 5.

Collyns, C. and Senhadji, A., 2002. Lending booms, real estate bubbles and the Asian crisis, Working Paper WP/02/20, January, International Monetary Fund, Washington, DC.

Detken, C. and Smets, F., 2004. Asset price booms and monetary policy, ECB Working Paper, No. 364, May, European Central Bank, Frankfurt.

Diamond, P., 1965. 'National debt in a neoclassical growth model', American Economic Review, 55:1,126-50.

Diamond, P. and Mirrlees, J., 1978. 'A model of social insurance with variable retirement', Journal of Public Economics, 10:295-326. 
Duca, J.V., 2005. Mutual funds and the evolving long-run effects of stock wealth on US consumption, Working Papers 05-11, Federal Reserve Bank of Dallas.

Favara, G. and Song, Z., 2006. Imperfect information and housing price dynamics, University of Lausanne (unpublished).

Frankel, J., 2004. 'On the yuan: the choice between adjustment under a fixed exchange rate and adjustment under a flexible rate', Paper presented to IMF Seminar on the Foreign Exchange System, Dalian, 26-27 May.

Friedman, M. and Schwartz, A.J., 1982. Monetary Trends in the United States and the United Kingdom, University of Chicago Press, Chicago.

Gaber, P., 1990. 'Famous first bubbles', Journal of Economic Perspectives, 4(2):35-54.

Gouteron, S. and Szpiro, D., 2005. Excess monetary and asset prices (unpublished).

Grossman, G. and Yanagawa, N., 1993. 'Asset bubbles and endogenous growth', Journal of Monetary Economics, 31:3-19.

Gyourko, J., Mayer, C. and Sinai, T., 2006. Superstar cities, Working Paper, No. 12355, National Bureau of Economic Research, Cambridge, MA.

Herring, R. and Wachter, S., 2005. 'Bubbles in real estate markets', in W.B. Hunter, G.G. Kaufman and M. Pormerleano (eds), Asset Price Bubbles: the implications for monetary, regulatory and international policies, MIT Press, Cambridge, MA.

Hsiao, C., 2003. Analysis of Panel Data, Cambridge University Press, Cambridge, MA.

Hunter, W.C., Kaufman, G.G. and Pomerleano, M. (eds), 2005. Asset Price Bubbles: the implications for monetary, regulatory and international policies, MIT Press, Cambridge, MA.

Issing, O., 2002. 'Monetary policy in a world of uncertainty', Economie Internationale, Issue 4Q, Center for Economic Policy Research, London.

Kalra, S., Mihaljck, D. and Doenwald, C., 2000. Property prices and speculative bubbles: evidence from HK SAR, IMF Working Paper, January, International Monetary Fund, Washington, DC.

Kaufman, G.G., Hunter, W.C. and Pomerleano, M. (eds), 2003. Asset Price Bubbles: the implications for monetary, regulatory and international policies, MIT Press, Cambridge, MA.

Kindleberger, C., 1987. 'Bubbles', in J. Eatwell, M. Milgate and P. Newman (eds), The New Palgrave: A Dictionary of Economics, Stockton Press, New York:281.

King, I. and Ferguson, D., 1993. 'Dynamic inefficiency, endogenous growth and ponzi games', Journal of Monetary Economics, 32:79-104.

Ljungqvist, L. and Sargent, T.J., 2000. Recursive Macroeconomic Theory, MIT Press, Cambridge, MA. 
McKinnon, R.I., 2005. Exchange Rates under the East Asian Dollar Standard, MIT Press, Cambridge, MA.

Meltzer, A.H., 2003. A History of the Federal Reserve, Vol.I, University of Chicago Press, Chicago.

Mishkin, F.S. and White, E.N., 2003. 'US stock market crashes and their aftermath: implications for monetary policy', in W.B. Hunter, G.G. Kaufman and M. Pormerleano (eds), Asset Price Bubbles: The implications for monetary, regulatory and international policies, MIT Press, Cambridge, MA.

Morris, S. and Shin, H.S., 2002. 'The social value of public information', American Economic Review, 92:1,521-34.

Muth, J.F., 1961. 'Rational expectations and the theory of price movements', Econometrica, 29:315-55.

Obstfeld, M. and Rogoff, K., 1996. Foundations of International Macroeconomics, MIT Press, Cambridge, MA.

Ogawa, E. and Sun, L., 2001. 'How were capital inflows stimulated under the dollar peg system?', in T. Ito and A.O. Kruger (eds), Regional and Global Capital Flows: macroeconomic causes and consequences, University of Chicago Press, Chicago.

Okina, K. and Shiratsuka, S., 2005. 'Japan's experience with asset price bubbles: is it a case for inflation targeting?', in W.C. Hunter, G.G. Kaufman and M. Pomerleano (eds), 2005. Asset Price Bubbles: the implications for monetary, regulatory and international policies, MIT Press, Cambridge, MA.

Organisation for Economic Co-operation and Development (OECD), 2006. House price developments: the role of fundamentals, Economics Department Working Papers, No. 475, Organisation for Economic Co-operation and Development, Paris.

Ortalo-Magne, F. and Rady, S., 2006. 'Housing market dynamics, on the contributions of income shocks and credit constraints', Review of Economic Studies, 73:459-85.

Park, Y.C. and Park, W.A., 1995. 'Capital movements, real asset speculation, and macroeconomic adjustment in Korea', in S. Edwards (ed.), Capital Controls, Exchange Rates and Monetary Policy in the World Economy, Cambridge University Press, Cambridge.

People's Bank of China, 2006. China Monetary Policy Report, Quarter Four, People's Bank of China, Beijing.

Posen, A.S., 2006. Why central banks should not burst bubbles, Working Paper WP06-10, Institute for International Economics, Washington, DC.

Roubini, N., 2006. 'Why central banks should burst bubbles', International Finance, 9(1):87-107.

Saint-Paul, G., 1992. 'Fiscal policy in an endogenous output growth model', Quarterly Journal of Economics, 106:1,243-59. 
Samuelson, P.A., 1976. 'Economics of forestry in an evolving society', Economic Inquiry, 12:466-92.

Stein, J.C., 1995. 'Prices and trading volume in the housing market: a model with down payment constraints', Quarterly Journal of Economics, 110(2):379405.

Sun, L., 2006. Troubles from China's double identity as a trading power and a financially marginal country, Symposium of the Fifth WTO and China Academic Annual Meeting, 2006:10.

Tirole, J., 1985. 'Asset bubbles and overlapping generations', Econometrica, $53: 1,499-528$.

Trichet, J.C., 2005. 'Asset price bubbles and their implications for monetary policy and financial stability', in W.B. Hunter, G.G. Kaufman and M. Pormerleano (eds), Asset Price Bubbles: the implications for monetary, regulatory and international policies, MIT Press, Cambridge, MA.

United Nations (UN), 2006. Trade and Development Report 2006, United Nations Conference on Trade and Development, New York.

Ventura, J., 2004. Bubbles and capital flows, Meeting Papers 102, Society for Economic Dynamics, Storrs.

Wang, L., 2005. 'Law institutions shouldn't alleviate social credit and trade response', Chinese Real Estate Finance, No.5.

Weil, P., 1987. 'Confidence and the real value of money in an over-lapping generations economy', Quarterly Journal of Economics, 102:1-22.

White, E.N., 1990. 'When the ticker ran late: the stock market boom and crash of 1929', in E. White (ed.), Crashes and Panics: the lessons from history, DowJones Irwin, Homewood.

$\mathrm{Yi}, \mathrm{X}$., 2005. 'Dependence and influence of real estate on domestic financial sector', Modern Commercial Banks, No.4.

Yuan, Z. and Fan, X., 2003. 'Analysis of rational bubbles in real estate markets', Economics Studies, No. 3.

\section{Acknowledgments}

We are grateful to R. Caballero and A. Krishnamurthy, from whose papers we got many useful hints for our theoretical analysis. We are grateful to Yu Yongding, Gao Haihong, Huang Haizhou, Xu Mingqi, Hua Ming and other participants in the ninth conference of the China Society of World Economics for their excellent comments on our empirical analysis. We also would like to thank Eiji Ogawa and other participants in the seminar in Hitotsubashi University (Japan) for their useful advice on this paper. 